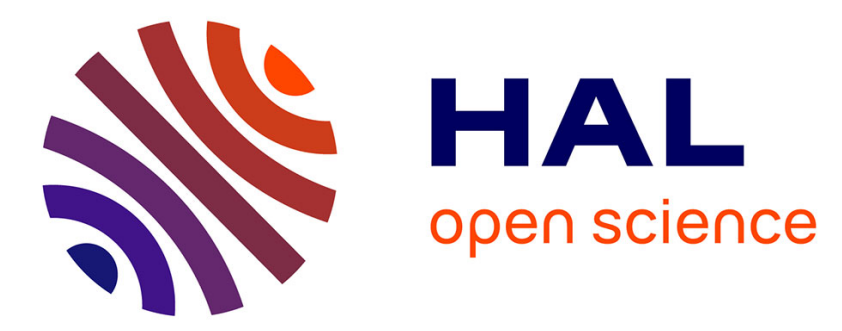

\title{
The role of Dutch in language practices in the Dutch-speaking periphery: The impact of Dutch on the Eastern Maroon Creoles
}

\author{
Bettina Migge
}

\section{- To cite this version:}

Bettina Migge. The role of Dutch in language practices in the Dutch-speaking periphery: The impact of Dutch on the Eastern Maroon Creoles. Revue Belge de Philologie et d'Histoire - Belgisch Tijdschrift voor Filologie en Geschiedenis, 2013, 91 (3), pp.1349-1364. hal-01495053

\section{HAL Id: hal-01495053 \\ https://hal.science/hal-01495053}

Submitted on 24 Mar 2017

HAL is a multi-disciplinary open access archive for the deposit and dissemination of scientific research documents, whether they are published or not. The documents may come from teaching and research institutions in France or abroad, or from public or private research centers.
L'archive ouverte pluridisciplinaire HAL, est destinée au dépôt et à la diffusion de documents scientifiques de niveau recherche, publiés ou non, émanant des établissements d'enseignement et de recherche français ou étrangers, des laboratoires publics ou privés.

$$
\text { Copyright }
$$




\section{Research Repository UCD}

Provided by the author(s) and University College Dublin Library in accordance with publisher policies. Please cite the published version when available.

\begin{tabular}{|c|l|}
\hline Title & $\begin{array}{l}\text { The role of Dutch in language practices in the Dutch-speaking } \\
\text { periphery: The impact of Dutch on the Eastern Maroon Creoles }\end{array}$ \\
\hline Author(s) & Migge, Bettina \\
\hline $\begin{array}{c}\text { Publication } \\
\text { date }\end{array}$ & 2013 \\
\hline $\begin{array}{c}\text { Publication } \\
\text { information }\end{array}$ & Revue Belge de Philologie et d'Histoire, 91 (3): 1349-1364 \\
\hline $\begin{array}{c}\text { Publisher } \\
\text { Item }\end{array}$ & Mouton De Gruyter \\
\hline $\begin{array}{l}\text { record/more } \\
\text { information }\end{array}$ & http://hdl.handle.net/10197/5840 \\
\hline
\end{tabular}

Downloaded 2017-03-21T19:58:06Z

The UCD community has made this article openly available. Please share how this access benefits you. Your story matters! (@ucd_oa)

Some rights reserved. For more information, please see the item record link above.

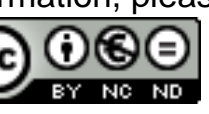




\title{
The role of Dutch in language practices in the Dutch-speaking periphery: the impact of Dutch on the Eastern Maroon Creoles
}

\author{
Bettina MigGE \\ University College Dublin
}

\section{Introduction}

Research on the Creoles of Suriname has focused on describing their structural system (Huttar \& Huttar 1994; Goury \& Migge 2003; McWhorter \& Good 2012; van den Berg 2007) and the processes that led to their emergence and early development (e.g. Huttar 1985; Arends 1989; Essegbey 2005; Migge 1998, 2002, 2003, 2006, 2011; Smith 2001; Lefebvre \& Loranger 2006; Winford \& Migge 2007). The focus of most of the latter research has been on the role and impact of African languages in the genesis of these creoles, but since creole formation crucially involved language contact, in this case between the languages of enslaved Africans who created the creole(s) and their European oppressors, there has also been some discussion on the nature of the English and Portuguese input and its role in the formation of these languages (Arends 1999; Smith 1987, 1999). By contrast, there is very little discussion on the role of the Dutch input to the formation and development of these languages (Arends 1989; Smith 1987) because Dutch was not well represented in Suriname during the early years.

Although Dutch has functioned as Suriname's official language since 1667 , it has not always played an important role in the country (de Kleine 2002: 209). In the $17^{\text {th }}$ and during most of the $18^{\text {th }}$ century most of the predominantly male European population was made up of Sephardic and Ashkenazi Jewish planters who spoke varieties of Spanish, Portuguese and German, respectively, French planters and some British colonists. They appear to have had little incentive to learn Dutch and mostly used their native language and Sranantongo, the language closely associated with enslaved Africans in Suriname, to fill their communicative needs (de Kleine 2002: 210 ). During the $18^{\text {th }}$ century Dutch became associated with the small group of freed black people and people of mixed African and European descent. While we lack detailed data about them, it appears that some of them were very well educated and became quite powerful within the local administration and business world. It is thus quite plausible that they were "functionally bilingual in Sranan[tongo] and Dutch, and may very well have used the latter regularly in social life, if only as a way to distinguish themselves from other less fortunate non-whites." (de Kleine 2002: 211). It is likely that this group of bilinguals was the founder of the Surinamese variety of Dutch. It gained 
currency later when its speakers started to outnumber Europeans and attained greater social power during the early $19^{\text {th }}$ century.

Another factor that led to the rise and spread of Dutch in Suriname was education. Dutch medium education was made compulsory in 1876 leading to increased access to and emphasis on Dutch among mostly urban dwellers because Dutch had now become an important vehicle for social advancement (de Kleine 2002: 214). However, since most of the children learned it as an additional language in the school context, its implementation in education also prompted the emergence of new varieties of Dutch that bore multiple influences from other languages, particularly Sranantongo, which was widely spoken as an L1 and an L2 and continues to serve as the main lingua franca of Suriname. Although these L2 varieties of Dutch became widespread because of the predominance of L2 speakers and a lack of change in learning conditions during the $19^{\text {th }}$ and most of the $20^{\text {th }}$ century, the impact of European Dutch has not diminished significantly. It still functions as the norm and increased migration to the Netherlands since independence has also increased contact with European Dutch for ordinary Surinamese citizens through family members living in the Netherlands. Today, Dutch is still the language of government, the only medium of instruction at all levels of education and the main means for social advancement. In recent year, English has been rising in importance particularly in professional domains and increased contact with other CARICOM (Caribbean Community) countries. While Dutch is traditionally associated with formal and certain status-elevating contexts, there are a growing number of Dutch/local language bilinguals who make use of Dutch outside of formal contexts as well. In informal interactions, it is quite common for people to engage in code-switching and code-mixing (Auer 1999, 1995). That is, people employ two or more languages within the same interaction, alternating between a local language and/or Sranantongo and Dutch, for instance. Dutch is also still widely used in the media (radio, TV) though there is increased competition from other languages such as English and Portuguese (TV) and local languages (radio).

Apart from some descriptive work focusing on exploring the differences between Surinamese and European Dutch (de Kleine 1999, 2002) and the impact of Sranantongo on Dutch (Essed 1983), there is also some sociolinguistic work on Dutch in Suriname which focuses on the distribution of phonological features and attitudes to varieties of Dutch (Charry 1983). There aren't any recent corpus-based studies on spoken, written or mediated use of Dutch in Suriname. Although Dutch clearly impacts on all the languages of Suriname, there is no systematic work on its influence. The aim of this paper is to examine the impact of Dutch on contemporary Eastern Maroon Creoles (Ndyuka and Pamaka). Based on an examination of interactions recorded since 1994 with both rural and urbanized Eastern Maroons and members of different age groups in urban and rural contexts and recordings of features on the Surinamese Maroon radio station Koyeba, I will explore the kinds of Dutch-based practices that are found in these recordings and assess their impact. The paper argues that rural adult Maroons traditionally make relatively little use of Dutch restricting their use to individual lexical items. These items were probably also 'appropriated' through Sranantongo rather than via direct contact with Dutch. The items tend to be phonologically adapted and linked to certain semantic domains. By contrast, younger people and especially those that align with urban culture make more frequent and sustained 
use of Dutch, including code-switching. The Dutch elements used by them are not heavily linguistically integrated, if at all, and belong to different social domains. Alternation between Eastern Maroon, Sranantongo and Dutch forms appears to be part of their regular language use.

The paper starts out with a brief discussion of the role of Dutch in Maroon communities showing that it did not play an important role there until urbanization started to increase rapidly in the 1980s. The second part examines the role of Dutch in different kinds of social contexts. The final section summarizes the findings and discusses their implications.

\section{Maroons and Dutch: Some historical notes}

Despite having been a Dutch colony since 1667, the influence of Dutch in Suriname only started to increase during the $19^{\text {th }}$ century with the rise in importance of a local, non-European elite and the introduction of compulsory Dutch medium education. However, this development primarily took place in the country's main urban area, Paramaribo, where the local elite resided and where educational institutions had been established. Outside of this area, contact with Dutch has grown in step with the development of educational facilities and migratory flows, but overall continues to remain less intense, even today. Maroon and Amerindian populations have traditionally had the least amount of contact with Dutch because their traditional village communities were located furthest from the urban areas, only received mostly primary school educational facilities from the 1970s onwards and have traditionally had little sustained and intense contact with the urban, Dutch speaking population. ${ }^{(1)}$

During the early part of the history of Maroon communities, most of their members had little or no sustained contact with Dutch. Prior to their flight from the plantations some of the people who were later to become Maroons might have been in contact with Dutch-speaking overseers or planters, but given that interactions between enslaved Africans and Europeans generally lacked intensity and complexity (i.e. were generally not amicable) and involved the use of Sranantongo rather than European languages, this is unlikely to have resulted in more than the learning of isolated words or phrases from Dutch. Following their flight, contact between Europeans and Maroons was rare and conflictual. European troops actively pursued Maroons in order to return them to enslavement or to decimate them as a way of removing the threat that they posed to plantation society. After the middle of the $18^{\text {th }}$ century, contacts were still hostile, but increased somewhat in the case of the two larger Maroon communities, the Ndyuka and Saamaka, because the colonial government was trying to negotiate a peace treaty with them. However, negotiations were not very frequent, involved only a few Maroon men and

(1) Some Amerindian populations such as the Kari'na and the Arawak who have traditionally resided in the coastal areas have had more sustained contact with urban populations (see Carlin \& Boven 2002). They also acculturated earlier and to a greater extent to urban cultural and linguistic patterns than the Amerindian populations traditionally resident in the interior such as the Trio. Note also that formal education in interior locations was severely disrupted between the late 1980s and ca. 2005 due to the civil war in Suriname and its consequences. 
were most likely carried out in Sranantongo as the treaty documents are also in that language (van den Berg \& Arends 1994). Following the conclusion of the treaties, there was some increase in contacts. First, a government official, posthouder, was placed in the village of the paramount chief (gaanman) to keep an eye on the activities of these Maroon groups. Second, although Maroons were initially formally forbidden to settle in town, they could, with permission travel to town for trading purposes or for negotiation with the colonial government. Van Stipriaan (to appear) estimates that at any given time between a handful to about 50 Maroons were present in Paramaribo. Among them were the so-called ostagiers, "sons of leading Maroons who stayed as political hostages in the colonial capital to guarantee peace". Delegations consisting of up to 90 Maroon men frequently came to the city for various negotiations, including the handing over of runaways, and often stayed for a few weeks. Many Maroon men also sold lumber to the colony (van Stipriaan to appear). Third, after the middle of the $19^{\text {th }}$ century Herrenhutter missionaries started missionary work in Saamaka. Although they were initially not very successful in converting Saamaka people to their Christian faith, their presence in Saamaka territory nevertheless exposed those Maroons that got into contact with them to a particular European life style and culture (Lenders 1996). From the end of the $19^{\text {th }}$ century, contacts between Maroons and the rest of the society, particularly the urban or coastal populations intensified further due to Maroons' involvement in many newly emerging economic activities. For instance, the discovery of gold on the Lawa River at the end of the $19^{\text {th }}$ century brought many people from the coast and members of other Maroon communities to the Aluku Maroon area. People often stayed for relatively long periods of time and worked closely with the many Maroon men who found employment as guides and boatmen. Maroon men were also involved in the large-scale exploitation of rubber trees in the late $19^{\text {th }}$ and early 20st century, the shipping of cargo on the Marowijne River, the laying of railway tracks in the Para region in the early 20st century and the mining of Bauxite in the 1940s (van Stipriaan to appear). Due to these developments Maroons' (men's) exposure to city culture including language practices increased gradually. However, it is not clear that greater contact with mainstream society necessarily also resulted in Maroons' greater contact with Dutch as most work related encounters in this domain like male peergroup interactions were typically carried out in Sranantongo, the country's lingua franca which is also closely related to the languages of the Maroons.

After the middle of the 20st century, Maroons' exposure to Dutch started to change due to important social changes that were affecting these communities. A first event was the construction of the hydroelectric dam in the middle of the Saamaka Maroon territory in the early part of the 1960s. It led to the displacement of a great number of Saamaka to new villages that were more closely situated to the main urban area, Paramaribo, and could be accessed by road, considerably reducing travel time and expenses to the capital. This forced migration not only increased casual contact with city life, but eventually also spurred circular and permanent migration to Paramaribo (van Stipriaan to appear). Migration to the city by members from all the different Maroon communities was further enhanced by the fact that a number of new job opportunities emerged during this time. The government was expanding its workforce, a small industrial sector was developing and various new 
natural resource exploitation schemes came on stream. This allowed Maroon men in particular to find paid and often also permanent employment in town, putting them in a good position to bring their families to live with them in town. At the same time, the members of their extended family now had the opportunity to make regular and longer visits to town and to secure housing for their children in town in order to take up post-primary educational opportunities. While this new situation possibly only marginally increased adult Maroon's chances of learning and practicing Dutch since Sranantongo was widely used in the manual labor sector, this new situation had an important impact on their children as they were now able to access both higher quality primary education and secondary and professional education, significantly improving their access to Dutch.

The 1960s and 1970s also brought about changes with respect to education in the smaller towns and rural areas. Primary schools were set up in rural areas by both the churches and the colonial government in an effort to enhance Maroon and Amerindian populations' integration into the country's mainstream society. These schools functioned entirely in Dutch - only religious education was carried out through Sranantongo - and followed the same curriculum as that used in urban areas. Although this educational approach has many difficulties and is not necessarily conducive to acquiring a high competence in Dutch, it certainly created a presence, even if it was marginal, for Dutch in the Maroon communities. As a result of the presence of schools and teachers from town, aspects of Dutch were gradually entering Maroon's language practices. Although most Maroon children who were educated in the village setting did not reach a very high level of competence in Dutch, the establishment of schools enabled a number of young people, especially young men, to learn enough in order to pursue further education in town and/or get paid employment there. While they benefited from a much greater exposure to Dutch in the city, the overall educational success was initially not very high, forcing many of them to work in precarious manual labor jobs. While it is still the case that many Maroons in Paramaribo still live precarious lives residing on the town's periphery in substandard housing, there is now a small but growing group of professionals of Maroon origin who hold important positions in the national administration (Aviankoi $\&$ Apapoe 2009). The members of this group were often born, raised and educated in town. They tend to be fluent in at least Dutch, a Maroon Creole and/or Sranantongo, though many of them did not grow up in households where Dutch was the main or only family language. Exposure to languages other than their own Maroon language has intensified for all Maroons due to greater contact between members from different so-called ethnic or language groups and the greater availability of telecommunication such as TV, radio and internet. However, Dutch is only one of the languages that is involved in these contexts as, for instance, films on TV are often broadcast in English, and to a lesser extent in Portuguese, and some of the radio stations also broadcast in local languages.

\section{The role of Dutch in Maroon's language practices}

In this section I wxplore the role and impact of features from Dutch in the language practices of Eastern Maroons. In order to obtain a representative 
insight into the nature and distribution of Dutch-based elements in Maroon language practices, I examined the speech of people belonging to different social groupings. In previous publications (e.g. Migge and Léglise 2013), I have argued that (Eastern) Maroons traditionally distinguish between several social categories of adults: gaansama 'elders', kiyoo 'young men' and umanpikin 'women'. Elders are essentially the leaders of the community. They consist of the holders of official offices such as the gaaman 'paramount chief', the kabiten 'village and lineage head' and the basiya 'assistants to the gaanman and the kabiten' and important members of the community. The latter are typically well respected men who are in their 50s and older and younger men if they have a special importance in the community. The term kiyoo designates younger men roughly from their mid teens to their mid to late 30s. They constitute a special category in that they are supposed to engage and gain experience in the world beyond their local community. In the local community, they depend on the support of 'their' elders for most matters such as marriage, arbitration of problems etc. and they are typically not allowed to be active speaker-participants in sociopolitical meetings (kuutu), including arbitration meetings that concern their own affairs. The category of umanpikin is quite broad, including all women. Women are traditionally linked to the domestic sphere and women's status is much dependent on the number of children they have, the upkeep of their family and home and their sexual behavior. While women's lives are traditionally seen as unchangeable in that they should always be focused on caring (for a home, its members, the upkeep of the village), female elders are due special respect and are also consulted on community matters; however, they generally do not actively participate in public meetings. ${ }^{(2)}$ Due to the social changes that have affected these communities, a further social subdivision has emerged: rural versus urban Maroons. It is widely accepted now that urban Maroon women and men have different life-styles and consequently also at least partially different social and linguistic practices. In the remainder to this section I first examine the role of Dutch influence in the language practices of regular middle-aged villagers who have spent most or all of their lives living in the up-river village context. These women and men only rarely go to the urban areas of Suriname or French Guiana and tend to only spend short periods of time (two to three weeks) at a time in the urban areas. I will compare their use of Dutch based elements with that found in the practices of younger men, kiyoo, recorded both in the village context and in urban areas. The final part will look at the use of Dutch on the Surinamese Maroon radio Station Koyeba.

\section{1. Dutch and middle-aged villagers}

The analysis in this section is based on several recordings with villagers in two upriver Pamaka and one Ndyuka village that were recorded between the late 1990s and during 2000. The recordings mostly took place in informal

(2) In recent years, due to pressure from the national government, Maroon communities have created female kabiten positions in order to better take account of women's concerns. These women kabiten often deal mostly with the everyday matters of the community, but are increasingly also making their voices heard during formal meetings. 
contexts and involved mostly female members of extended family networks. Analysis of these recordings suggests that the influence from Dutch in these practices is restricted to the occurrence of lexical items or loan words from Dutch. Linguistically, they fall into two types: phonologically integrated loan words and those that are not. In all recordings, there are a number of elements that originally derive from Dutch, but have become an integral part of the Eastern Maroon lexicon. These items are in regular use in the language and often do not alternate with other indigenous words that have the same meaning. (3) That is, they have become fully integrated into the language and are best described as borrowings, namely foreign elements that have become integrated into the native language of a group by members of that group (Thomason \& Kaufman 1988: 37; Winford 2003: 12). These elements have also been adapted to the phonological structure of the Eastern Maroon varieties. For instance, the Dutch word wagen [waxən] (1) 'car' is realized as [wagi] in Eastern Maroon varieties. That is, the voiceless velar fricative [x] has been replaced by a voiced velar stop [g] and the syllable [ən] or [n] was replaced by [i] as the Eastern Maroon varieties do not have velar fricatives, the shwa vowel or vocalic nasals, prefer a CV structure, and have no word final alveolar nasals. In the case of other words, such as the Dutch verb verstaan [ferstaan] 'understand', realized as [fustan] in Eastern Maroon varieties (10), the final nasal was velarized, the initial vowel acquired a back quality $[\mathrm{u}]$ and was lengthened to compensate for the omission of $[\mathrm{r}]{ }^{(4)}$

The words from this category belong to several lexical classes. In the recordings examined, there were a number of nouns (1-5) that derived from Dutch nouns, a small number of Dutch adjectives (6-8) that functioned as attributive adjectives and as verbs in the Eastern Maroon varieties. ${ }^{(5)}$ There were also several items that derive from Dutch verbs that also function as verbs in the Eastern Maroon varieties (9-13). Finally, the recordings also

(3) For words such as wagi (1), masini (4), denki (9), fustan (10) and noyti (15) there are alternate expressions but they either have partially different meanings - masini refers to all kinds of mechanically driven entities while muntulu is mostly used to designate an outboard motor - or they have become stylistic options. Denki and particularly fustan but also noyti are closely associated with informal everyday speech while the indigenous counterparts yee 'understand, hear', kwetikweti 'never' and pakise (l)i 'think, imagine' or older forms oto, bakaboto 'car' are more closely associated with formal or negatively polite language use.

(4) In the speech of some people, the [st] consonant cluster was broken up by the insertion of the vowel [u], giving rise to [fus(u)tan].

(5) Note that there is not a true category of adjectives in the Eastern Maroon varieties, as these elements, also referred to as property items (Migge 2000), are verbs in predicative position (i), but adjectives in attributive position (ii). Muliki, for instance, may also function as a transitive verb meaning 'to bother' (iii).
(i) A sani be muliki.
DET thing PAST difficult
'The thing was difficult.'
(ii) $A$ wan muliki sani.
FOC DET difficult thing
'It's an annoying thing.'
(iii) Den muliki mi te.
they annoy me very
'They annoy me a lot.' 
included items that belong to other lexical classes such as prepositions (14), adverbs (15) and interrogative pronouns (16). Only one of the loanwords found in the recordings, buuse 'dislike someone intensely' appears to derive from a Dutch noun boosheid 'meanness' but is used as a verb in the Eastern Maroon varieties. Semantically, the loan words have maintained their core meanings.

Table 1: Loan words from Dutch in the Eastern Maroon varieties

\begin{tabular}{|r|l|l|l|}
\hline \multicolumn{2}{|c|}{ Dutch lexical items } & Eastern Maroon lexical item & Gloss \\
\hline 1 & wagen (N) & wagi (N) & car \\
\hline 2 & papier (N) & pampila (N) & paper \\
\hline 3 & kamer (N) & kamba (N) & room \\
\hline 4 & machine (N) & masini (N) & machine \\
\hline 5 & boodschap (N) & bosikopu (N) & message \\
\hline 6 & moeilijk (A) & muliki (A/V) & difficult \\
\hline 7 & gemakkelijk (A) & makiliki (A/V) & easy \\
\hline 8 & fejf (A) & feyfi (A) & five \\
\hline 9 & denken (V) & denki (V) & think/remember \\
\hline 10 & verstaan (V) & fustan (V) & understand \\
\hline 11 & kiezen (V) & kisi (V) & get, catch \\
\hline 12 & spuit (V) & spoyti (V/N) & spray, sprinkle, injection \\
\hline 13 & dwingen (V) & dwengi (V) & force, pressurize \\
\hline 14 & zonder (P) & sonde(e) (P) & without \\
\hline 15 & nooit (Adv) & noyti (Adv) & never \\
\hline 16 & sort (?) & sowtu (wh-word) & what kind, which \\
\hline
\end{tabular}

Besides so-called integrated loan words, the recordings also included a few loan words from Dutch that have undergone little change as part of their integration into Eastern Maroon practices, Table 2.

Table 2: Relatively unchanged lexical items from Dutch in Eastern Maroon speech

\begin{tabular}{|l|l|l|l|}
\hline \multicolumn{2}{|l|}{ Dutch lexical items } & Eastern Maroon lexical item & Gloss \\
\hline 1 & onderhouden $(\mathrm{V})$ & {$[$ ondahauen] $(\mathrm{V})$} & to keep up \\
\hline 2 & vrouw $(\mathrm{N})$ & {$[\mathrm{fr \mho u}] /[\mathrm{flvu}](\mathrm{N})$} & woman, wife \\
\hline 3 & nicht $(\mathrm{N})$ & {$[\mathrm{nIkt}](\mathrm{N})$} & niece \\
\hline 4 & openlijk (Adv) & {$[$ openlik] (Adv) } & openly, obviously \\
\hline 5 & echte $(\mathrm{A})$ & {$[\mathrm{ekte}](\mathrm{A})$} & real \\
\hline 6 & rij $(\mathrm{V})$ & {$[\mathrm{rey}] /[\mathrm{ley}](\mathrm{V})$} & drive \\
\hline 7 & mooi $(\mathrm{A})$ & {$[\mathrm{moy}](\mathrm{A} / \mathrm{V})$} & nice \\
\hline 8 & gauw $(\mathrm{Adv})$ & {$[\mathrm{gaw}](\mathrm{A} / \mathrm{Adv})$} & fast, quick \\
\hline
\end{tabular}

For instance, in examples (3) and (5) in Table 2 the velar fricatives are realized as velar stops but the consonant clusters are not broken up and the loan in (4) maintains a word final consonant that conflicts with the Eastern Maroon phonotactic structure. The loans given in (7-8) seem to not have changed at all possibly because their phonological structure is not in conflict 
with that of Eastern Maroon varieties. In the case of elements (2) and (6), there is variation in the realization of the liquid. Among traditional villagers and in more formal styles (6) is quite consistently realized as [ley] while formally educated villagers tend to alternate between [ley] and [rey] (see below). In terms of their relative status within the lexicon of Eastern Maroon varieties, they are rather variable. While moy and gaw, for instance, are fully integrated, others (1-5) vary with indigenous lexical items with the same meaning (luku, uman, sisa, duun, tuutuu/gaan, respectively). ${ }^{(6)}$

\subsection{The influence of Dutch in the practices of younger people}

An examination of recordings involving mostly younger men (kiyoo) that took place in the rural communities and in urban contexts reveals a somewhat different picture. In these informal peer group interactions young(er) men are at pains to display their alignment with the urban context. Apart from social practices such as clothing and work, code alternation practices involving urban-marked codes play a vital role in this process (Migge \& Leglise 2013). The recordings I examined for this section show a fair amount of alternation between distinctive elements and structures from the Eastern Maroon Creoles, the related urban lingua franca Sranantongo and elements associated with Dutch and English. Younger men also make regular use of so-called integrated loan words from Dutch (Table 1) as they are a regular part of the language. We find words like wagi, sonde(e), and also others such as kowoon < gewoon 'commonly', wenk $(l) i<$ winkel 'shop', tali < taal 'language', lagi < laag 'low', floisi/froisi < verhuizen 'move house', bii(r)ti < buurt 'neighborhood' and kufaliki < gevaarlijk 'dangerous'. However, what distinguishes younger men's practices from those of typical village practices is that they involve a much higher incidence of elements from Dutch and these items also show little integration suggesting that these young men have some degree of knowledge of Dutch. In the interactions examined, elements from other languages, and particularly Dutch, were found in nearly every turn at talk. Extract (1) illustrates this.

\section{Extract 1}

Wat is er? Je ziek?: quip. Koers, maralia, bun pipi ya, hoofdpijn. No man, koers man, da na echte, man. Koers, da na sirjes, man. Den wan dati na libi yere, ma den kan beri un a ganda ya e bali, mi de lengilengi ya da i kon ya, mi taki, mi taki: "No, mi án be si tok san e pasa tok ya."

Dutch: underlined; English: italics

'What's up, are you sick: ??. A cold, malaria, a lot of urinating, headache. No man, a cold man, that's a real issue man. A cold, that's serious man. These things, that's life, listen, but they can bring us down, I am lying in my

(6) Moy was initially probably synonymous with the indigenous word bun. Both terms are still sometimes used interchangeably, but moy appears to have more positive overtones than bun in some contexts, i.e. mi de bun 'I'm ok.' versus mi de mooy 'I'm doing well'; while moy is used to describe the appearance of objects and beings, bun is used to describe their constitution. 
hamoc here, then you come here and I say: "No, I did not see, right, what is happening here, right."”

In Extract (1), the speaker starts out with two short sentences in Dutch and then continues in a shared Sranantongo/Eastern Maroon frame into which he inserts words from Dutch and one from English belonging to different lexical categories. They all have indigenous counterparts and are best described as instances of code-mixing. The insertion of non-Eastern Maroon elements including short sentences functions to assert membership in the group of young men and to highlight their alignment with the world beyond the village community. In the recordings examined, most of the insertions involved single words that were embedded in an Eastern Maroon/ Sranantongo frame (1). There were also a small number of loan translations from Dutch that involved both Dutch and Eastern Maroon words (2). The occurrence of entire phrases in Dutch was marginal.

(1) a. I sabi fa mi ben habi haast. 'You know how I've been under time pressure.'

b. Mi wani go tu yere man ernstig. 'I want to go too, man, I'm serious.'

c. Neks (<niets) mi na abi. Kowoon den man si mi, yon. 'I have nothing. They just saw me, man.'

d. Vijftien gram a o gi mi, mi tevreden. 'He will give me 15 grams of gold, I'm happy with that.'

e. Ma i poti wan aantal go de ... 'But you put a certain amount over there...'

(2) a. Yu na mi rechte anu yu sabi ala sani. 'You are my right hand, you know everything.'

b. Da u e krois abra. 'Then we cross (< cross over) here.'

One aspect that is particularly emblemic of these speech practices is the use of ingroup identity marking particles such as brother, man etc. and agreement markers. They usually occur at the end of the phrase and encode a solidarity relationship. Some of the most frequently used markers of this kind derive from Dutch, e.g. tok < toch, yon < jongen, man. ${ }^{(7)}$

(3) a. Da mi o bay wan broko wagi, yon. 'Thus I'll buy a broken car, man.'

b. Zaterdag, zondag, ya man. 'Saturday, Sunday, yes man.'

c. A sani á mu e bigi tumisi gi i tok. 'You should not make it into a big issue, right.'

\section{3. The use of Dutch on the radio programme Koyeba}

The rapid growth of the urban Maroon population especially since the 1980s has led to the emergence of a new generation of Maroons who have

(7) Man also means 'male person, (generic) person' in the Eastern Maroon varieties. However, it is not generally used as a marker. The fact that this marker is mainly used by urbanized people with access to Dutch or who are part of a network with access to Dutch makes it more likely that its in-group marker use derives from Dutch. 
grown up only or mostly in the urban context. They are usually well integrated into their respective ethnic, e.g. Ndyuka, Pamaka, networks but tend to have little experience with the village context as they rarely or never go upriver due to the prohibitive cost associated with such trips. While younger urban Maroons are at pains to emphasize that they are well-integrated into mainstream, that is urban Surinamese society, ${ }^{(8)}$ ethnic and extended familybased networks remain dense and multiplex among urban Maroons. Many of the younger Maroons, unlike their elders, do not view being a Maroon and being urban as incompatible, but actively seek to bring them together. One medium that has proven to be rather popular in this respect is the radio. Since the radio market in the region was opened up, a number of radio stations and programmes have been established that broadcast in local languages in both Suriname and French Guiana. Among the most popular programmes/stations are two that are run by and focus on contemporary Maroon culture, namely Loweman Pansu in western French Guiana (Migge 2011) and Koyeba in Suriname. ${ }^{(9)}$

Koyeba is a Maroon-owned radio station in Paramaribo that was founded in October 1997 by Paulus Abena. It broadcasts seven days a week from about 6 am to 1 am on 104.9 FM. ${ }^{(10)}$ The programme is realized by a team of broadcasters of Maroon origin that are locally referred to as basia 'assistants'. According to their website, their target audience are the Surinamese population and particularly Maroons (binnenlandbewoners) thereof, but they stress that non-Maroons also listen to their programme. ${ }^{(11)}$ Based on their own estimates, $70 \%$ of their emissions are in Maroon languages such as Aucaans (Ndyuka) and Saramaccaans and 30\% in other languages, mostly Dutch and some English. ${ }^{(12)}$ Koyeba's programme is quite varied. One aspect that appeals to most Maroons is the fact that they play a lot of music, both Surinamese music styles, particularly styles associated with Maroons, and international ones. Music is played between programmes and sometimes also partially overlays them. The programme features include health matters, political issues, discussions about cultural issues, cooking, news, death notices and advertising for both events and shops.

Analysis of the language used on the radio station reveals that varieties of Ndyuka are most widely used by both the presenters and callers while Saamaka and Matawai play a less important role overall. Some of the presenters and people who call in also speak Sranantongo or rather an urban register of Ndyuka that is heavily influenced by Sranantongo. Compared to the other

(8) This is equally true of Maroons who have made (urban) French Guiana their home.

(9) The spelling conventions for both does not respect existing conventions: Loweman Paansu 'descendants of the runaways' and Kon yee baa 'come listen please'.

(10) It can nowadays also be received via online stream: radiokoyebasuriname.com.

(11) The wording in somewhat ambiguous - De uitzendingen van Radio Koyeba zijn gericht op de Surinaamse samenleving maar de binnenlandbewoners in het bijzonder. At the end of the section, set off from the rest of the text and in bold it says: Tot slot mag met trots worden vermeld dat naast de grote groep luisteraars (binnenlandbewoners), in groeiende mate, ook NIET Marroons (overige Surinamers) naar Radio Koyeba luistert. Getuige de 'feedback' vanuit het luisterpubliek.

(12) For naming of Maroon languages see Migge \& Léglise (to appear) and Léglise \& Migge (to appear). 
two settings discussed above, Dutch figures more prominently on the Koyeba radio station though it probably does not attain $30 \%$ or $20 \%$ of the total spoken discourse. Since most of the people who speak on Koyeba are younger or middle-aged urban Maroons, they code-mix between Maroon varieties, Sranantongo and Dutch. As in the case of the recordings with younger men (section 2.2.), elements from Dutch regularly figure in their speech. What is however noteworthy here is the fact that they are drawn from a wide range of semantic fields and are often presented with a hyper-Dutch pronunciation. The words that contain phonemes that are not found in the Maroon Creoles, particularly the alveolar trill [r] and the velar fricatives [xy], are prominently realized, possibly to display the speaker's superior knowledge of Dutch compared to the village population. Especially any kind of information that pertains to administrative and national government related matters tends to be heavily sprinkled with words from Dutch that are also not phonologically integrated. Discussions of music, advertising of events and more relaxed interactive features make less heavy use of Dutch, involving alternation between distinctive Eastern Maroon elements, elements from Sranantongo and some common Dutch and/or English elements. There are no programme features that are entirely presented in Dutch. However, some of the ads that are periodically broadcast throughout the day such as ads from major shops dealing with things like matrasses or electronic devices are at times presented completely in Dutch and there does not appear to be a Maroon version. This contrasts with ads for smaller shops such as hair saloons and clothes, but also major food stores and stores regularly frequented by Maroons which are often presented in Ndyuka, possibly involving a few specialist words from Dutch. The ads are often presented by the basias themselves rather than by people from outside of the radio station.

The distribution of languages on Koyeba is clearly reflective of (urban) Maroon language practices. It suggest that while Maroon languages are still an integral part of Maroon communities and remain the main means of communication, Dutch has been making inroads into these networks. In the urban context it has become a natural part of people's everyday lives. In order to negotiate their alignment with urban Surinamese culture, people who speak on Koyeba are eager to display their control over 'proper' Dutch. This is accomplished by both voicing phonemes that are locally marked as distinctively Dutch and by selectively retaining minor texts such as some ads or certain death notices entirely in Dutch - in some cases they are also presented in both languages.

\section{Conclusion}

This paper set out to examine the role of Dutch in the language practices of Eastern Maroons. It argued that Dutch took a hold in Suriname due to two events, namely the rise to power of a mixed urban elite during the $19^{\text {th }}$ century and the fact that Dutch was made the compulsory medium of education in the late $19^{\text {th }}$ century. However, both events did not have much of an effect on the populations living in the interior of Suriname as they did not have much sustained contact with the urban areas until the middle of 
the 20st century. Schools were only mainstreamed in the late 60 s and early 70s and many Maroon children only acquired a basic knowledge of Dutch. Competence in Dutch among Maroons only increased when great numbers of Maroons started to settle in urban areas and Maroon children attended school there. While there are still a good number of Maroons in Suriname, including the urban areas, who only have basic knowledge of Dutch, the number of Dutch-Maroon Creole bilinguals is clearly on the rise throughout the country.

Evaluation of language practices among middle-aged villagers, younger men and on the Maroon radio station Koyeba strongly suggest that Maroon languages remain central to Maroon's networks. However, Dutch is slowly filtering into ingroup practices. Middle-aged villagers who either did not attend formal education or had little sustained contact with it make relatively little use of Dutch overall. They only sparsely integrate a small set of single lexical items that tend to be phonologically adapted to Maroon phonotactic patterns in their practices. By contrast, younger men's practices are characterized by code alternation patterns in which elements from Dutch and Sranantongo are quite prominent (cf. Migge 2007). Most of these men completed post-primary education and can thus draw on a relatively broad set of vocabulary from Dutch. However, many of them are not very fluent in the language and tend to prefer to interact in a Maroon Creole and make use of frequent insertions from Dutch and other languages as a way of displaying their urban sophistication (and differentiate themselves from the image of the prototypical villager). Finally, speakers on the Maroon radio station Koyeba who predominantly live in Paramaribo and were often also born and raised there make much more liberal use of Dutch. They selectively emphasize their competence in Dutch by applying hyper-Dutch pronunciations and by integrating shorter texts entirely in Dutch in untranslated manner in their broadcasts. Viewed from a diachronic perspective, the analysis suggests that bilingual or multilingual practices in which Dutch is one of the players are clearly on the rise as they embody younger Maroon's desire to position themselves as member of mainstream Surinamese society.

\section{References}

ARENDS (Jacques): 1989, Syntactic developments in Sranan, Unpublished dissertation, Catholic University of Nijmegen.

ARENDS (Jacques): 1999, 'The origin of the Portuguese element in the Surinam creoles', in Spreading the word: The issues of diffusion among the Atlantic Creoles. (London: University of Westminster Press), pp. 195-208.

AUER (Peter): 1995, 'The pragmatics of code-switching: a sequential approach, in MILROY (Lesley) and MUYSKEN (Pieter), eds. One speaker, two languages: Cross-disciplinary perspectives on code-switching. (Cambridge: Cambridge University Press), pp. 115-135.

AUER (Peter): 1999, 'From code-switching via language mixing to fused lects: towards adynamic typology of bilingual speech', International Journal of Bilingualism, 3, pp. 209-332.

AVIANKOI (Ema) and APAPOE (Ire): 2009, 'Leven in de stad. Maroons intransitie', in VAN STIPRIAAN (Alex) and POLIMÉ (Thomas), eds. Kunst van overleven: Marrooncultuur uit Suriname. (Amsterdam: KIT-Publishers), pp. 156-63. 
CHARRY (Eddy): 1983, 'Een sociolinguïstische verkenning von het SurinaamsNederlands', in CHARRY (Eddy), KOEFOED (Geert) and MUYSKEN (Pieter), eds. De talen van Suriname: Achtergronden en ontwikkelingen. (Muiderberg: Dick Coutinho): pp. 138-161.

DE KLEINE (Christa): 2002, 'Surinamese Dutch', in CARLIN (Eithne B.) and ARENDS (Jacques), eds. Atlas of the languages of Suriname. (Leiden: KITLV Press), p. 209-230.

DE KLEINE (Christa): 1999, A morphosyntactic analysis of Dutch as spoken by the Creole population of Suriname, unpublished dissertation. (Ann Arbor: University of Michigan International).

ESSED (Eva): 1983, 'De veranderende status van het Sranan', in CHARRY (Eddy), KOEFOED (Geert) and MUYSKEN (Pieter), eds. De talen van Suriname: Achtergronden en ontwikkelingen. (Muiderberg: Dick Coutinho): pp. 47-52.

GOURY (Laurence) and MIGGE (Bettina): 2003, Grammaire du nengee: introduction aux langues aluku, ndjuka et pamaka. (Paris: IRD Éditions).

HUTTAR (George): 1985, 'Sources of Ndjuka African vocabulary', New West Indian Guide, 59, pp. 45-71.

HUTTAR (George) and HUTTAR (Mary): 1994, Ndyuka. (London: Routledge).

LEFEBVRE (Claire) and LORANGER (Virgine): 2006, On the properties of Saramaccan FU: synchronic and diachronic perspectives, Journal of Pidgin and Creole Languages, 21, 2, pp. 275-336.

LÉGLISE (Isabelle) and MIGGE (Bettina): to appear, Language practices and language ideologies in Suriname: Results from a school survey. In CARLIN (Eithne B.), LÉGLISE (Isabelle), MIGGE (Bettina) and TJON SIE FAT (Paul), eds. In and out of Suriname: Language, mobility, identity. (Leiden: KITLV).

LENDERS (Maria): 1996, Strijders voor het Lam. (Leiden: KITLV).

MCWHORTER (John) and GOOD (Jeff): 2012, A grammar of Saramaccan Creole. (Berlin: De Gruyter Mouton).

MIGGE (Bettina): 2011, 'Negotiating social identities on an Eastern Maroon radio show', Journal of Pragmatics, 43, 6, pp. 1495-511.

MIGGE (Bettina): 2006, 'Tracing the origin of modality in the creoles of Suriname', in DEUMERT (Ana) and DURRLEMAN (Stephanie), eds. Structure and Variation in Contact Languages. (Amsterdam: John Benjamins), p. 29-59.

MIGGE (Bettina): 2003, Creole Formation as Language Contact: The Case of the Surinamese Creoles. (Amsterdam: John Benjamins).

MIGGE (Bettina): 2002, 'The origin of the copulas $(d / n) a$ and $d e$ in the Eastern Maroon Creole', Diachronica, 19, 1, pp. 81-133.

MIGGE (Bettina): 2000, 'The origin of the syntax and semantics of property items in the Surinamese Plantation Creole', in MCWHORTER (John H.), ed. Language Change and Language Contact in Pidgins and Creoles. (Amsterdam: John Benjamins): pp. 201-34.

MIGGE (Bettina): 1998a, 'Substrate influence in creole formation: the origin of give-type serial verb constructions in the Surinamese Plantation Creole', Journal of Pidgin and Creole languages, 13, 2, pp. 215-65.

MIGGE (Bettina) and LÉGLISE (Isabelle): to appear, Assessing the Sociolinguistic Situation of the Maroon Creoles, Journal of Pidgin and Creole Languages.

MIGGE (Bettina) and LÉGLISE (Isabelle): 2013, Exploring language in a multilingual context: Variation, interaction and ideology in language documentation. (Cambridge: Cambridge University Press).

SMITH (Norval): 2001, 'Voodoo chile: differential substrate effects in Saramaccan and Haitian', in SMITH (Norval) and VEENSTRA (Tonjes), eds. Creolization and Contact. (Amsterdam: John Benjamins), pp. 43-81. 
SMITH (Norval): 1999, 'Pernambuco to Surinam 1654-1665? The Jewish slave controversy', in HUBER (Magnus) and PARKVALL (Mikael), eds. Spreading the word: The issues of diffusion among the Atlantic Creoles. (London: University of Westminster Press), pp. 251-298.

SMITH (Norval): 1987, 'The genesis of the Creole language of Surinam', unpublished dissertation, The University of Amsterdam.

THOMASON (Sarah G.) and KAUFMAN (Terrence): 1988, Language Contact, Creolization, and Genetic Linguistics. (Berkeley: University of California Press).

VAN DEN BERG (Margot): 2007, A Grammar of Early Sranan. (Zetten: Drukkerij Manta).

VAN DEN BERG (Margot) and ARENDS (Jacques): 2004, 'The Saramaka peace treaty in Sranan: an edition of the 1762 text (including a copy of the original text)', Creolica (www.creolica.net).

VAN STIPRIAAN (Alex): to appear, 'Maroons and the communications revolution in Suriname's interior', in CARLIN (Eithne B.), LÉGLISE (Isabelle), MIGGE (Bettina) and TJON SIE FAT (Paul) eds. Mobilities inside and out of Suriname. (Leiden: KITLV).

WINFORD (Donald): 2003, An Introduction to Contact Linguistics. (Oxford: Blackwell).

WINFORD (Donald) and MIGGE (Bettina): 2007, 'Substrate influence on the emergence of the TMA systems of the Surinamese creoles', Journal of Pidgin and Creole Languages, 22, 1, pp. 73-99.

\section{ABSTRACT}

Much of the research on the creoles of Suriname has explored the origin and development of these languages. This research has predominantly focused on the role of the African languages that were spoken by the enslaved population. There has also been some work on the provenance of the European component, particularly English and Portuguese lexical items (Smith 1987). By contrast we know relatively little on the Dutch influence on the Creoles of Suriname. In this paper make a small contribution towards filling this gap by investigating the use of Dutch elements in a set of recordings that were made over the last 20 years with Eastern Maroons resident in rural and urban locations and with recordings coming from a Maroon radio station. The discussion shows that unintegrated or little integrated Dutch lexical items are filtering into Maroons' language practices, particularly into the practices of those people who are living in urban contexts and are in regular contact with Dutch. While older, rural dwellers tend to make very little sustained use of them, younger people who have received a certain level of formal education make use of Dutch in code-switching practices in certain kinds of status-elevating contexts to negotiate their alignment with modern conceptions of maroon-ness.

\section{RÉSUMÉ}

Beaucoup de la recherche entreprise sur les créoles du Suriname a exploré l'origine et le développement de ces langues. Cette recherche s'est surtout focalisée sur le rôle des langues africaines qui furent parlées par les populations d'esclaves. Il y a également eu un intérêt pour l'origine de la composante européenne, particulièrement les éléments anglais et portugais (Smith 1987). A l'inverse, on ne sait que relativement peu sur l'influence néerlandaise sur les créoles du Suriname. Cet article se veut contribuer à combler cette lacune en examinant l'utilisation d'éléments néerlandais 
dans un ensemble d'enregistrements qui ont été effectués les 20 dernières années parmi des marons orientaux résidant en zones rurales et urbaines, ou qui proviennent d'une station radio maronne. Je démontre que des éléments néerlandais peu intégrés ou non-intégrés font partie intégrante des pratiques langagières maronnes, particulièrement des pratiques de ces personnes qui vivent dans un context urbain et sont en contact régulier avec le néerlandais. Alors que les personnes plus âgées habitant en zone rurale ne tendent qu'à faire un usage limité de ces éléments néerlandais, les personnes plus jeunes qui ont eu accès à une éducation formelle font usage du néerlandais au sein de pratiques d'alternance codique dans une gamme de contextes où la projection d'un statut social élevé est en jeu, afin de négocier leur alignement avec des conceptions modernes de l'identité maronne.

\section{SAMENVATTING}

Veel van het onderzoek naar de creoolse talen van Suriname heeft zich toegespitst op de oorsprong en de ontwikkeling van deze talen. Dit onderzoek heeft hierbij voornamelijk aandacht geschonken aan de rol van de Afrikaanse talen die door de slavenbevolking gesproken werden. Er is ook wat aandacht geschonken aan de oorsprong van de Europese component, in het bijzonder van de Engelse en Portugese elementen (Smith 1987). Daartegenover weten we relatief weinig over de invloed van het Nederlands op de creoolse talen van Suriname. Dit artikel wil ertoe bijdragen deze leemte in te vullen door het gebruik van Nederlandse elementen te analyseren in een reeks opnames die tijdens de laatste 20 jaren gedaan werden onder oostelijke Maroons die in plattelandse en stedelijke gebieden wonen, alsmede in opnames die van een Maroons radiostation verkregen werden. De discussie toont aan dat niet of weinig geïntegreerde Nederlandse lexicale elementen doorsijpelen in Maroon taalgebruik, in het bijzonder in het taalgebruik van die mensen die in stedelijke contexten wonen of die in regelmatig contact met het Nederlands staan. Terwijl oudere mensen op het platteland heel weinig gebruik maken ervan, maken jongere mensen die toegang kregen tot het onderwijs gebruik van het Nederlands via code-switching. Dit gebeurt in bepaalde contexten waarbij hun sociale status op het spel staat en ze hun vereenzelviging met een moderne interpretatie van de Maroonidentiteit willen uiten. 